\title{
ANNOUNCEMENT
}

\section{THE AFRICAN ASSOCIATION OF INSECT SCIENTISTS (AAIS)}

The African Association of Insect Scientists (AAIS) was founded in 1978. The objectives of the Association are to promote and advance knowledge on all aspects of insect science in Africa. It does this by publishing the AAIS bulletin, conference proceedings, co-sponsorship of the journal Insect Science and Its Application and by organising international conferences on topical issues pertaining to insect science in the tropics. Recent international biennial conferences were held in Ghana, Nigeria, Egypt, Liberia, Senegal and Zambia.

Membership of the Association is open to all those interested in insect science in Africa. A registration fee of US \$20 and an annual subscription of US\$20 are payable and this entitles members to attend all conferences organised by the Association, receive the AAIS bulletin and discount on subscription to Insect Science and Its Application.

The subscription rate for members to the bimonthly journal Insect Science and Its Application:

$\begin{array}{lr}\text { One Volume (6 Issues) } & \$ 20 \\ \text { Single Issues } & \$ 5 \\ \text { Two Volume } & \$ 38\end{array}$

Please send your order to:

Subscription Department ICIPE Science Press

P.O. Box 72913

NAIROBI, Kenya

East Africa

Full details on membership may be obtained on request from the Honorary Secretary, AAIS, P.O. Box 59862, Nairobi, Kenya (Telephone: Nairobi 802501/3/9/10,Telex:22053, Fax:803360).

\section{APPLICATION FORM}

I/We would like to apply for membership of AAIS

Name

Affiliation

Address

Type of membership applied for $\quad$ Life Member $\square \quad$ Ordinary Member $\square \quad$ Student

Amount Cheque No.

Money Order

Please return this form to:

Hon. Treasurer

AAIS

P.O. Box 59862

NAIROBI

Kenya 